\title{
SEASONAL DISTRIBUTION AND ROUTES OF PRONGHORN IN THE NORTHERN GREAT BASIN
}

\author{
Gail H. Collins ${ }^{1}$
}

\begin{abstract}
Pronghorn (Antilocapra americana) exhibit complex spatial and temporal variation in seasonal movements and range use across their distribution. However, knowledge of seasonal movements, routes, and distribution of pronghorn within the sagebrush-steppe of the northern Great Basin is lacking. From October 2011 to October 2013, I monitored movements of adult female pronghorn across an area of over 1.5 million hectares along the northwestern Nevada and southeastern Oregon border using GPS/VHF-equipped collars. I used 68,834 GPS locations from 32 female pronghorn to determine migration timing, seasonal distributions, individual fidelity to winter and summer ranges, and population-level routes used during the migration period. Collared pronghorn were conditionally migratory, with $65 \%$ migrating an average of $30.0 \mathrm{~km}$ the first year and 100\% migrating an average of $39.1 \mathrm{~km}$ the second; one individual migrated over $160 \mathrm{~km}$ between summer and winter ranges. Seasonal ranges averaged $143.3 \mathrm{~km}^{2}$ during the summer, and from 252.9 to $459.9 \mathrm{~km}^{2}$ during the winter (2010/2011 and 2011/2012, respectively). Individual pronghorn demonstrated wide variation in directional movement between summer and winter ranges, and there was high overlap of common areas across seasons and time periods. Pronghorn showed stronger fidelity to summer ranges than to winter ranges, and occupied higher elevations during the summer months, descending to lower elevations during the winter. Deeper snow and colder temperatures in 2012/2013 compared to 2011/2012 corresponded to longer average migration distances, fewer exploratory movements, larger winter ranges, lower elevational use, and a shift in winter range location. Habitat conversion, degradation, and fragmentation have accumulated across the sagebrush-steppe biome and are negatively affecting the long-term persistence of dependent wildlife. Applying knowledge of important seasonal use areas and routes used during migration in future conservation planning can mitigate impacts to pronghorn habitat and provide for long-term conservation.
\end{abstract}

RESUMEN.-El antílope americano (Antilocapra americana) tiene una variación espacial y temporal compleja durante su movimiento migratorio estacional y su rango de utilización a lo largo de su distribución. Sin embargo, el conocimiento sobre los movimientos estacionales, las rutas y la propagación de los antílopes en la estepa-artemisa al norte de la Gran Cuenca (Great Basin) es insuficiente. Desde octubre del 2011 a octubre del 2013, monitoreé los movimientos de hembras adultas en una área de más de 1.5 millones de hectáreas a lo largo de la frontera del noroeste de Nevada y sudeste de Oregon utilizando collares equipados con GPS/VHF. Utilicé 68,834 ubicaciones de GPS de 32 antílopes hembras para determinar el momento de migración, las distribuciones estacionales, la fidelidad individual en los períodos de invierno y verano, y las rutas a nivel poblacional utilizadas durante el período de migración. Los antílopes con collares migraron condicionalmente. Un $65 \%$ migró un promedio de $30.0 \mathrm{~km}$ el primer año, mientras que el $100 \%$ migró un promedio de $39.1 \mathrm{~km}$ el segundo año, con una migración individual de más de $160 \mathrm{~km}$ entre los períodos de verano e invierno. Los rangos estacionales fueron en promedio de $143.3 \mathrm{~km}^{2}$ durante el verano, y entre 252.9 y $459.9 \mathrm{~km}^{2}$ durante el invierno (2010/2011 y 2011/2012, respectivamente). Los antílopes mostraron una variación amplia, individualmente, en su desplazamiento direccional entre los rangos de verano e invierno, y hubo superposición de las áreas comunes entre las estaciones y los períodos de tiempo. Los antílopes mostraron mayor fidelidad a los rangos de verano que a los de invierno, y ocuparon alturas más elevadas durante los meses de verano, descendiendo a menores alturas durante el invierno. Nieve más profunda y temperaturas más frías en 2012/2013 en comparación con las de 2011/2012 correspondieron a un promedio de distancias de migración más largas, menores movimientos exploratorios, rangos de invierno más grandes, el uso de alturas más bajas y un cambio en el rango de ubicación en invierno. La transformación del hábitat, la degradación y la fragmentación se han acumulado a través del bioma de estepa-artemisa y han afectado negativamente la permanencia a largo plazo de la fauna dependiente. Aplicar el conocimiento sobre el uso de las áreas estacionales importantes y sobre el uso de las rutas durante la migración durante la planificación de la conservación futura, pueden mitigar el impacto en el hábitat del antílope americano y contribuir a su conservación a largo plazo.

Across their range, pronghorn (Antilocapra americana) distribution and migratory movements are affected by human activities and infrastructure. Human barriers (e.g., roads, fences) can restrict pronghorn movements within or between seasonal ranges, limit daily movements, and reduce available habitat (Gates et al. 2012). Pronghorn have also experienced

${ }^{1}$ United States Fish and Wildlife Service, Box 111, Lakeview, OR 97630. E-mail: gail_collins@fws.gov 
behavioral changes and reductions in carrying capacity across their range due to decreased habitat and fragmentation of migration routes as a result of development, fencing, and other land-use practices (e.g., Sawyer et al. 2005, Boccadori et al. 2008, Beckmann et al. 2012, Seidler et al. 2014). The challenge of conserving migratory ungulates is due to their wide-ranging seasonal movements, which occur across both a diversity of ecosystems and varying land management priorities (Copeland et al. 2014). For example, Berger (2004) estimated that $75 \%$ of the migration routes for bison (Bison bison), elk (Cervus canadensis), and pronghorn have been lost in the Greater Yellowstone region. And, although it is an important life history component for many species, migration is often overlooked during conservation planning efforts (Saher and Schmiegelow 2005, Berger et al. 2014).

Strong female site fidelity and social inheritance of learned travel routes appear to be important factors for pronghorn in maintaining access to discrete summer and fawning ranges (Barnowe-Meyer et al. 2013). These factors coupled with both low relative population abundance and disturbance, which contribute to the loss of experienced individuals, may prevent recolonization of unoccupied habitat patches, potentially leading to route abandonment and cessation of migration (Gustafson and Gardner 1996, Avital and Jablonka 2000, Piper 2011, Barnowe-Meyer et al. 2013). Further, although pronghorn do commonly display migratory behavior between distinct summer and winter ranges, and are adapted to moving long distances (O'Gara and Yoakum 2004), not all populations or individuals in those populations migrate annually with consistency; some populations or individuals may at times move only short distances between seasonal ranges (Hoskinson and Tester 1980, Boccadori and Garrott 2002, White et al. 2007, Jacques et al. 2009b).

The sagebrush (Artemisia spp.) biome is one of the most widespread components of western U.S. landscapes. However, this ecosystem has also been identified as one of the most imperiled in the United States (Noss et al. 1995), and it is being fragmented and degraded at an increasing rate by multiple stressors (Knick et al. 2003, Schroeder et al. 2004, Davies et al. 2011). Invasive plants, wildfires, and climate change are all major influences on sagebrush habitats and present significant challenges to long-term conservation (Wisdom et al. 2005, Miller et al. 2011). Habitat conversion for human purposes, energy and mineral development, and a long history of both dispersed and intensive uses such as off-highway vehicles, domestic livestock grazing, and wild horse and burro management have contributed to widespread loss and decline of habitat quality and associated wildlife populations (Manier et al. 2013). As such, a large-scale conservation effort is currently underway across 11 western states to reduce threats to the sagebrush ecosystem, with specific focus on protecting the Greater Sage-Grouse (Centrocercus urophasianus; Chambers et al. 2014). Pronghorn are also widely distributed throughout the sagebrush-steppe of the northern Great Basin and are highly valued for hunting and wildlife viewing opportunities. However, there is little empirical data documenting landscape movements across the northern distribution of pronghorn due to the difficulty of monitoring individuals that move long distances (Jacques et al. 2009b). Although limited information is available (e.g., Kindschy et al. 1982, Trainer et al. 1983, Foster 1988), even fewer empirical investigations (e.g., Dalton 2009) have occurred within the western peripheral range of pronghorn occupying the northern Great Basin. This contributes to challenges for long-term conservation of pronghorn, because there is uncertainty about the distribution of seasonal habitats, location of migration routes, impacts of land-use practices, and effects of other potential barriers (Berger et al. 2006, White et al. 2007). There is also uncertainty in how large-scale conservation efforts underway for other species (e.g., Greater Sage-Grouse) could potentially overlap efforts to conserve pronghorn (Copeland et al. 2014). In this study, I documented the movements of adult female pronghorn in southeastern Oregon and northwestern Nevada during 2011-2013 to examine connectivity between 2 summering populations and to develop a baseline for identifying seasonal movement patterns and timing, seasonal distributions, individual fidelity to seasonal use areas, and migration distances and routes in the northern Great Basin.

\section{Study AREA}

Pronghorn were captured on summer ranges within Sheldon National Wildlife 


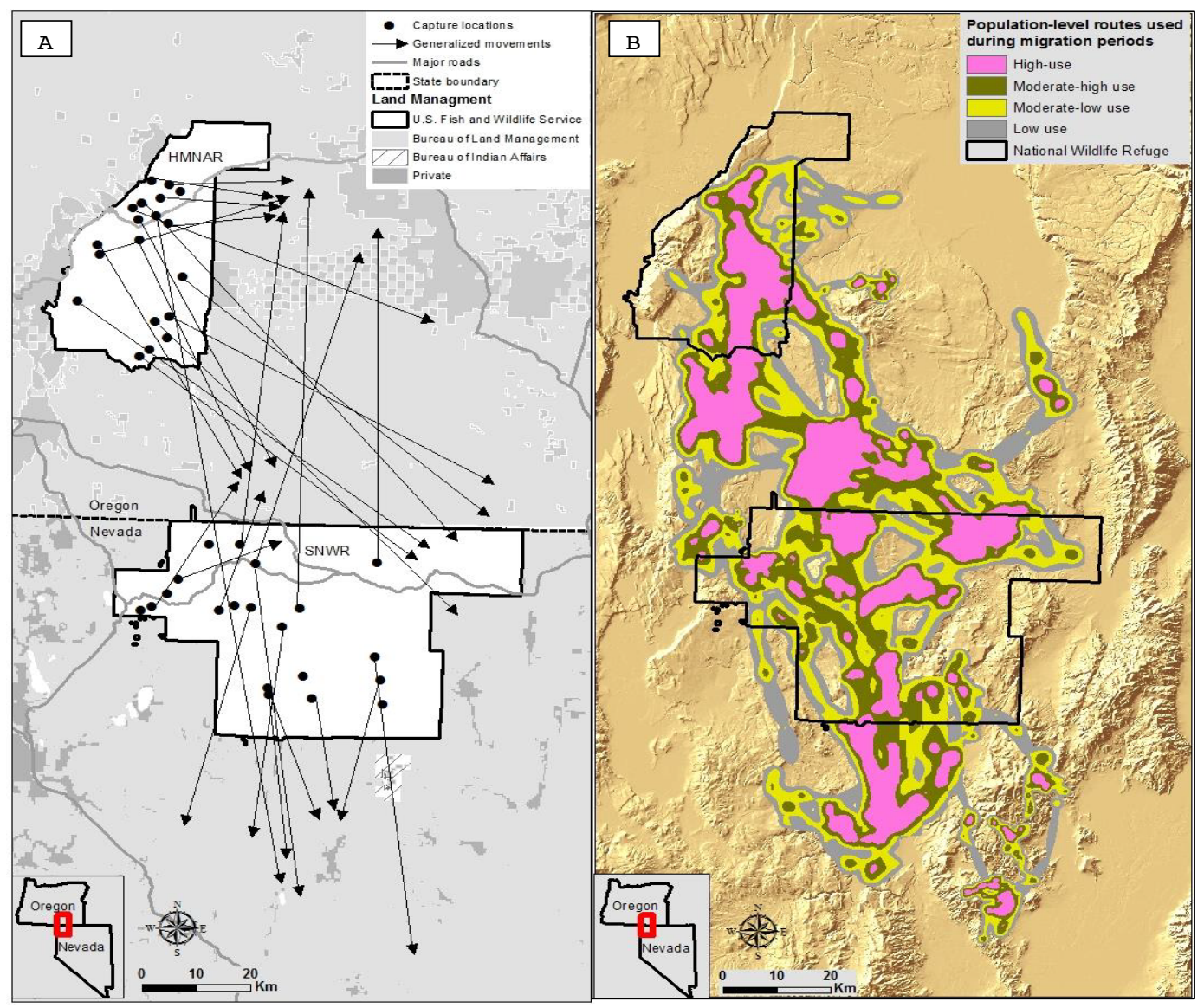

Fig. 1. (A) Pronghorn capture locations, generalized directional movements between summer and winter ranges, and land ownership. (B) Population-level routes used by female pronghorn during migration periods, southeastern Oregon and northwestern Nevada, 2011-2013.

Refuge (SNWR) and Hart Mountain National Antelope Refuge (HMNAR), managed jointly by the U.S. Fish and Wildlife Service, in northwestern Nevada and southeastern Oregon, respectively (Fig. 1A). The 2 national wildlife refuges were created in the early 1930 s primarily as conservation areas for a declining pronghorn population. Together the refuges currently protect over 344,000 ha $\left(3440 \mathrm{~km}^{2}\right)$ of some of the last intact examples of the sagebrush-steppe ecosystem in North America. The 2 wildlife refuges jointly supported summer populations of roughly 3600 pronghorn (Collins 2014a, 2014b), and were an inset of the larger study area of approximately $1,525,665$ ha $\left(15,250 \mathrm{~km}^{2}\right)$. My study area consisted almost entirely of public federal lands (90\%) managed by the U.S. Fish and
Wildlife Service (23\%) and the Bureau of Land Management (67\%). The Summit Lake Indian Reservation (Bureau of Indian Affairs) accounted for $0.3 \%$, and the remaining roughly $10 \%$ of the lands within the study area were privately owned or county- or state-managed (Fig. 1A). Controlled, male-only harvest for pronghorn was permitted during the fall on public lands during the study. Season dates in Oregon were early August to mid-September, and in Nevada were early August to early September and late September to late October. Hunting in the larger area has generally been restricted to a relatively low number of limited tags with staggered seasons and dispersed hunting opportunities.

Elevations across the area range from 1320 $\mathrm{m}$ to 2640 m (HMNAR: 1448-2443 m; SNWR: 
1326-2183 m). Recent summer temperatures range from $0{ }^{\circ} \mathrm{C}$ to $34{ }^{\circ} \mathrm{C}$ and winter temperatures range between $-29^{\circ} \mathrm{C}$ and $14{ }^{\circ} \mathrm{C}$; annual precipitation rarely amounts to more than 30 $\mathrm{cm}$. Dominant vegetation consists of shrubs, particularly sagebrush (Artemisia spp.), and associated sagebrush-steppe habitats. Scattered open woodlands consisting of western juniper (Juniperus occidentalis) or curl-leaf mountain mahogany (Cercocarpus ledifolius) occupy ridgelines and some slopes. Aspen (Populus spp.) and willows (Salix spp.) are found in dispersed snowpockets and in areas of persistent water. Talus and broken rock habitats are found along the edges of tabletops and escarpments, and along steep side-slopes.

\section{Methods}

In early October 2011, we captured 39 adult ( $>2$ years old) female pronghorn by using accepted capture protocols for netgunning from a helicopter. Helicopter pursuit time was generally $<2$ min to limit capturerelated mortalities, and pronghorn were processed at the capture site and released without transportation to another location to minimize handling stress (Jacques et al. 2009a). Total handling time (from pursuit to release) averaged $8.4 \mathrm{~min}$ per individual. Each captured pronghorn was briefly restrained, blindfolded, and monitored by a veterinarian during handling. Capture crews recorded capture location, sex, body condition, and an age estimate based upon incisor wear and replacement (Dow and Wright 1962). Blood samples were collected by venipuncture of the jugular vein for disease evaluation. Crews then attached to each pronghorn a store-on-board global positioning system (GPS) collar outfitted with a very high frequency (VHF) transmitter and a remote-release mechanism (Model G2110D, Advanced Telemetry Systems, Isanti, $\mathrm{MN})$. Each collar was programmed to remotely detach after 2 years to allow recovery from the field.

The GPS collars were distributed widely across the 2 wildlife refuges in order to capture variation in movements (Fig. 1A). They were programmed to obtain location fixes every $5.5 \mathrm{~h}$; $99 \%$ of the GPS fix attempts were successful. Each collar also recorded elevation $(\mathrm{m})$ and temperature $\left({ }^{\circ} \mathrm{C}\right)$ at each location. I also used average daily temperature $\left({ }^{\circ} \mathrm{C}\right)$ and snow depth $(\mathrm{cm})$ data averaged from 5 SNOTEL sites located in the vicinity of the study area (Natural Resources Conservation Service 2014) to compare overall winter severity across the study area between years. We located collared pronghorn via VHF-equipped fixed-wing aircraft within 2 weeks of capture and then approximately every $2-3$ months to check their status and general location.

To categorize seasonal use, I used ArcGIS 10.0 (Environmental Systems Research Institute, Redlands, CA) to estimate the migration start and end date for each individual. I defined spring migration as seasonal movement from winter to summer range and fall migration as seasonal movement from summer to winter range. Exploratory movements were defined as movements observed during the fall migration period in which the individuals did not travel directly toward their eventual winter range, but initially traveled away from or bypassed through the wintering area before returning. I defined individual migration start dates as the first location that deviated $\geq 5 \mathrm{~km}$ from a seasonal range and was associated with successive directional movements (Kolar et al. 2011). To omit locations associated with migration or exploratory movements from seasonal range calculations, I defined seasonal ranges (winter and summer) as the time period 1 day after the last marked animal's arrival date to 1 day prior to the first marked animal's departure date.

I used Geospatial Modelling Environment (GME; Spatial Ecology 2013) and ArcGIS to calculate $95 \%$ and $50 \%$ kernel density estimates for individual annual summer and winter seasonal ranges. The $50 \%$ kernel density estimates from individual pronghorn by season were combined to estimate population-level seasonal core use areas. ArcGIS was used to determine the geographic center of seasonal ranges $(95 \%$ kernel), and to measure the distance between geographic center points to estimate migration distances and seasonal range fidelity for individuals surviving 2 consecutive seasons (Jacques et al. 2009b). I noted a break in the overlap of seasonal ranges for pronghorn that migrated and for those that were nonmigratory, therefore I defined migration as seasonal movement between winter and summer ranges that overlapped in area by $<15 \%$. Nonmigrating individuals were defined by winter and summer ranges that 
overlapped by $>15 \%$. ArcGIS was also used to measure the straight-line distance between an individual's consecutive locations, and those distances were summed per day to estimate daily travel distances.

I followed the approach of Horne et al. (2007) and Sawyer et al. (2009) to identify both individual and population-level routes used by pronghorn during the migration period. I used the Brownian bridge movement model package (BBMM; Nielson et al. 2013) for R (R Development Core Team 2013) to estimate a utilization distribution (UD) for individual pronghorn for each migration period using data collected from sequential GPS locations from collared animals. I used a grid size of $50 \times 50 \mathrm{~m}$ and an estimated location error of $20 \mathrm{~m}$ because $94 \%$ of the GPS locations were 3-dimensional (3-D) fixes, which generally have $<20 \mathrm{~m}$ of error (Di Orio et al. 2003, Sawyer et al. 2009). The UDs from individual pronghorn were combined to provide an estimate of the relative amount of use across a population-level route, and were categorized into quartiles such that the top 25\% represented "high use" and the lowest 25\% represented "low use" (Sawyer et al. 2009). Routes estimated by the BBMM provide measures of both time spent in an area and the rate of movement; therefore, high-use areas would be representative of where animals spent more time (e.g., foraging, resting), and moderate-use areas would represent where animals moved through more quickly (e.g., movement corridors) (Sawyer et al. 2009).

I compared pronghorn elevational use, migration distances, and home-range sizes between seasons and years using paired $t$ tests (SYSTAT, Software Inc., Richmond, CA). I considered $P \leq 0.05$ as statistically significant.

\section{RESUlTS}

Of the 39 adult female pronghorn that were collared originally, 5 either shed their collars $(n=3)$ or died $(n=2)$ within $45 \mathrm{~d}$ of capture and were not included in further analyses. No data were recovered from an additional 2 collars that malfunctioned due to unknown reasons. The 5\% failure rate we experienced is at the lower limit of GPS device failures reported by Hebblewhite and Haydon (2010). The remaining 32 GPS collars collected 68,834 locations between October 2011 and October
2013. Individuals were followed for an average of $497 \mathrm{~d}$ (SD 218) and yielded an average of 2151 locations (SD 940).

Pronghorn that summered within Hart Mountain NAR and Sheldon NWR demonstrated wide variation in directional movements to winter ranges (Fig. 1A). Pronghorn captured on Hart Mountain NAR in Oregon were the most varied and far-ranging in their movement patterns, and individual animals were observed (1) remaining on HMNAR during winter, (2) moving to winter ranges in Oregon to the east, (3) moving south to winter ranges located in Oregon between the 2 refuges, or (4) continuing to move into Nevada to winter either on Sheldon NWR or farther south. For pronghorn captured on Sheldon NWR, individuals were observed (1) remaining on SNWR during winter, (2) moving north to winter ranges in Oregon, or (3) moving to winter ranges south of SNWR in Nevada. Pronghorn departed their summer ranges between late September (first departure 28 September) and late November, arriving at winter ranges by midDecember (last arrival 15 December). In the spring, pronghorn left their winter ranges between early March (first departure 7 March) and early May, arriving at summer ranges by mid-May (last arrival 13 May). The median departure date for fall migration was 11 October (SD $14.2 \mathrm{~d}$ ) and for spring migration was 8 April (SD 18.9 d). Very few $(\leq 3)$ marked individuals had the same initiation date for any given migration period and none were observed traveling together during periodic aerial surveys; therefore, I assumed movement was independent of other collared pronghorn (Saher and Schmiegelow 2005). Previous research efforts had identified the pronghorn fawning season for the study area as 11 May-14 June (U.S. Fish and Wildlife Service unpublished data). Seasonal dates were identified as 16 December-6 March for winter ranges and 11 May-27 September for summer ranges (adjusted to include the start of fawning).

Overall, GPS-collared pronghorn moved an average of $4.7 \mathrm{~km} \cdot \mathrm{d}^{-1}$ (SD 3.3). Movement rates for individual pronghorn peaked during fall migration, averaging $5.8 \mathrm{~km} \cdot \mathrm{d}^{-1}(\mathrm{SD}$ 1.1, $n=32$ ) for fall 2011 and $6.2 \mathrm{~km} \cdot \mathrm{d}^{-1}$ (SD 1.8, $n=24$ ) for fall 2012. Female pronghorn moved the least during the fawning season, averaging the same distances for both 2012 
TABLE 1. Summary of average elevations and seasonal area sizes used by female pronghorn, southeastern Oregon and northwestern Nevada, 2011-2013.

\begin{tabular}{|c|c|c|c|c|c|c|c|c|c|}
\hline \multirow[b]{2}{*}{ Time period } & \multicolumn{3}{|c|}{ Elevation $(\mathrm{m})$} & \multicolumn{3}{|c|}{$95 \%$ range $\left(\mathrm{km}^{2}\right)$} & \multicolumn{3}{|c|}{$50 \%$ range $\left(\mathrm{km}^{2}\right)$} \\
\hline & $n$ & $\bar{x}$ & $\mathrm{SD}$ & $n$ & $\bar{x}$ & SD & $n$ & $\bar{x}$ & SD \\
\hline Winter 2011/2012 & 31 & 1778.3 & 84.2 & 31 & 252.9 & 192.6 & 31 & 61.5 & 46.9 \\
\hline Summer 2012 & 29 & 1834.7 & 133.7 & 28 & 168.6 & 274.9 & 28 & 29.3 & 38.5 \\
\hline Winter 2012/2013 & 20 & 1565.9 & 82.4 & 19 & 459.9 & 532.8 & 19 & 100.5 & 120.6 \\
\hline Summer 2013 & 12 & 1808.2 & 139.4 & 10 & 117.9 & 117.9 & 10 & 23.3 & 16.2 \\
\hline
\end{tabular}

$(\bar{x}=3.8 \mathrm{~km}, \mathrm{SD} 1.3, n=29)$ and $2013(\bar{x}=$ $3.8 \mathrm{~km}, \mathrm{SD} 0.9, n=12)$. The greatest distance moved in a single day was $37.9 \mathrm{~km}$ by an individual returning from winter to summer ranges in early May 2012. The shortest distance was $0.18 \mathrm{~km} \cdot \mathrm{d}^{-1}$ during fawning in early June 2012 .

For pronghorn that survived at least through the start of summer $2012(n=29)$, only $2(7 \%)$ did not return to the same summer range on which they were originally captured in October 2011. Individuals that survived 2 consecutive summers (2012 and 2013) demonstrated stronger fidelity to summer ranges than to winter ranges, returning to within 5.7 $\mathrm{km}$, on average, of the previous summer range (SD $5.4 \mathrm{~km}, n=12$ ). There was no difference in the size between years for either $95 \%$ or $50 \%$ summer ranges $(95 \% t=0.569, \mathrm{df}=36$, $P=0.573 ; 50 \% t=0.478, \mathrm{df}=36, P=0.636$ ) (Table 1). Therefore I pooled the summer range data among years for individuals for subsequent analyses. In contrast, individuals demonstrated weaker fidelity to winter ranges, averaging $39.1 \mathrm{~km}$ between consecutive winter ranges $(\mathrm{SD} 29.4 \mathrm{~km}, n=19)$. The mean $95 \%$ winter range size was also larger in $2012 / 2013$ than in 2011/2012 $(t=-1.974$, df $=$ $48, P=0.054)$; there was no difference in $50 \%$ winter range sizes between years $(t=-1.618$, $\mathrm{df}=48, P=0.112$; Table 1$)$. In addition to increases in the size of the area used, there was also an overall locational shift in the wintering areas to the east between 2011/2012 and 2012/2013 (Fig. 2A).

During 2011/2012, five of 31 pronghorn did not migrate (16\%); 1 individual shed its collar during late fall migration and thus was not included in this analysis. Of the remaining individuals, $20(65 \%)$ made seasonal migrations between summer and winter ranges and 6 (19\%) made short-distance (<20 km) migrations to adjacent seasonal areas. Average distance for those who migrated (i.e., seasonal ranges overlapped by <15\%) short distances to adjacent ranges was $10.3 \mathrm{~km}$ (SD 5.1, $n=$ 6 ), and average distance for those that migrated to nonadjacent ranges was $30.0 \mathrm{~km}$ (SD 15.6, $n=20$ ). In contrast, in 2012/2013 all of the remaining collared individuals exhibited migration movements to nonadjacent ranges $(\bar{x}=39.1 \mathrm{~km}$, SD 29.4, $n=19)$, including 9 pronghorn who either did not migrate $(n=4)$ or only migrated short distances to adjacent ranges in the previous year $(n=5)$. Average distance between summer and winter seasonal ranges was significantly farther in 2012/2013 $(\bar{x}=44.9 \mathrm{~km}, \mathrm{SD} 27.1, n=19)$ than in $2011 / 2012(\bar{x}=23.1 \mathrm{~km}, \mathrm{SD} 16.0, n=31)$ $(t=-3.584, \mathrm{df}=48, P=0.001)$. The farthest distance documented was $160.2 \mathrm{~km}$ for an individual during the fall 2012 migration between summer range on Hart Mountain NAR in Oregon and winter range south of Sheldon NWR in Nevada.

Utilization distributions (UDs) were estimated for 60 individual routes during the 4 migration periods. Individuals who did not migrate or whose distance-moved was too short to identify a discrete route were excluded from this analysis. The average Brownian motion variance (BMV) outputs, which quantify how diffusive or irregular the path of an animal is (Sawyer et al. 2009), were as follows: fall 2011, 13,085 $\mathrm{m}^{2}$ (SE 8144, $n=23$ migrations); spring $2012,6558 \mathrm{~m}^{2}$ (SE $3800, n=16$ migrations); fall 2012, 10,373 $\mathrm{m}^{2}$ (SE 5512 , $n=16$ migrations); and spring $2013,8791 \mathrm{~m}^{2}$ (SE $3149, n=5$ migrations). These calculations included data from individuals who were either nonmigratory or short-distance migrators in 2011/2012 but who made exploratory movements during the fall migration period before returning to wintering areas either within or adjacent to their respective summer ranges. Indeed, 76\% of migrating individuals made exploratory movements - sometimes very long-distance ones (e.g., >260 km)—during the fall migration period before returning 


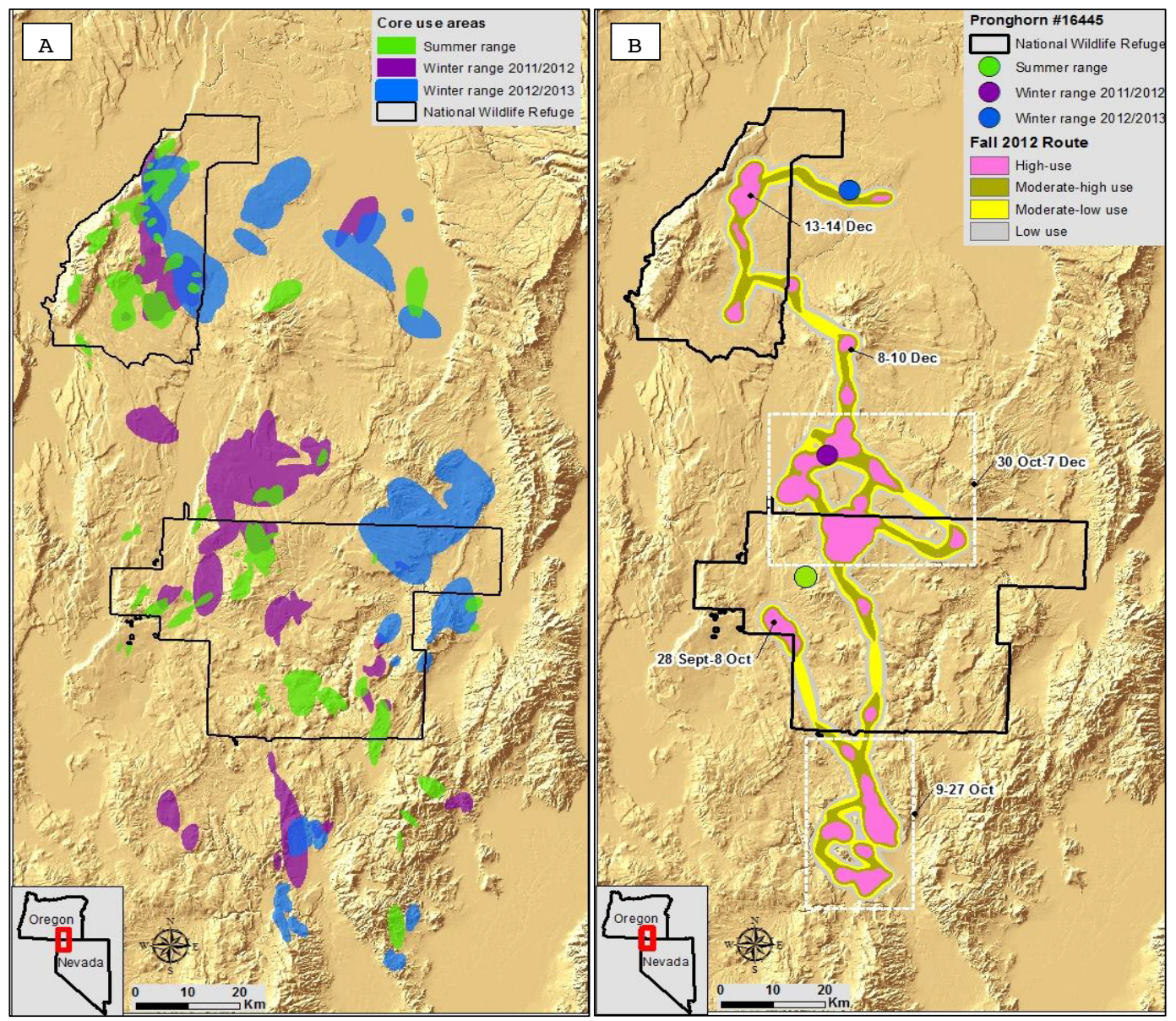

Fig. 2. (A) Estimated population-level seasonal core use areas (50\% kernel) for summer ranges (green) and winter ranges (2011/2012 [purple] and 2012/2013 [blue]). (B) Example exploratory movements made by date between summer range (geographic center, green) and 2012/2013 winter range (geographic center, blue) during the fall 2012 migration period of pronghorn \#16445, southeastern Oregon and northwestern Nevada.

and settling on their respective winter ranges (e.g., Fig. 2B). Though exploratory movements most often occurred during fall 2011, two individuals also made such movements during fall 2012; similar exploratory movements were not observed during the spring migration period.

At the population level, collared pronghorn used a network of common routes during the migration periods to access and return from their respective winter ranges (Fig. 1B). The population-level routes represent a probabilistic measure of where migration and exploratory movements likely occurred, characterized by high-use areas, where pronghorn spent the majority of their time, connected by moderate-use areas through which pronghorn moved more quickly (Sawyer et al. 2009; Fig. 1B). Overlap of seasonal ranges with populationlevel routes was high, and influenced by the wide variation in directional movements observed for both individual pronghorn and between years. Depending on the individual and the year, these common areas were utilized for both winter and summer ranges, but also for routes associated with migration and exploratory movements as individuals bypassed one another. As an example, pronghorn \#16445 summered on Sheldon NWR in Nevada and wintered in 2011/2012 on an adjacent range in Oregon just to the north of her summer range (Fig. 2B). However, the following year in fall 
2012 , she first left her summer range and traveled in the opposite direction from the previous year, to the south of Sheldon NWR in Nevada. After roughly 3 weeks, she returned north and spent a little over a month in the vicinity of her previous winter range in Oregon before continuing farther north, traveling through Hart Mountain NAR and settling on a winter range to the east of the refuge (Fig. 2B).

Collared pronghorn on average occupied similarly high elevations during both summers (Table 1). Pronghorn then moved to lower elevational winter ranges, although individuals occupied significantly lower elevations in winter 2012/2013 compared to winter 2011/2012 $(t=8.863, \mathrm{df}=49, P<0.000)($ Table 1$)$. Recorded ambient temperatures from the collars documented differences between the 2 winters, with temperatures in 2012/2013 being on average slightly cooler $\left(\bar{x}=6.6{ }^{\circ} \mathrm{C}\right.$ $\left[43.8{ }^{\circ} \mathrm{F}\right], \quad \mathrm{SD}$ 6.7) than temperatures in $2011 / 2012\left(\bar{x}=7.5^{\circ} \mathrm{C}\left[45.4^{\circ} \mathrm{F}\right]\right.$, SD 5.7). Temperatures averaged from the SNOTEL sites further support that the winter of 2012/2013 was cooler $\left(\bar{x}=-2.57{ }^{\circ} \mathrm{C}\left[27.4{ }^{\circ} \mathrm{F}\right]\right)$ than the previous winter $\left(\bar{x}=-0.86{ }^{\circ} \mathrm{C}\left[30.4{ }^{\circ} \mathrm{F}\right]\right.$ ) (Natural Resource Conservation Service 2014). The winter of 2012/2013 also recorded higher snow depths overall, averaging $38.2 \mathrm{~cm}$ compared to $29.1 \mathrm{~cm}$ in $2011 / 2012$; all of the 5 SNOTEL sites recorded an increase in snow depth of $17 \%-45 \%$ between the 2 years (Natural Resources Conservation Service 2014). Though snow accumulation during 2012/2013 was greater overall, the first date of measurable snowfall in 2011/2012 occurred nearly a month earlier (6 October 2011 vs. 24 October 2012) (Natural Resources Conservation Service 2014).

\section{Discussion}

Pronghorn in this study migrated from separate summering areas to a range of wintering areas in late September to mid-December, returning to summer ranges between early March and mid-May. Migration in this study generally coincided with migration timing reported for other pronghorn populations across their range (Oregon-Trainer et al. 1983, Foster 1988; Idaho-Hoskinson and Tester 1980; South Dakota-Jacques 2006; Wyoming-Sheldon and Lindzey 2006; Yellowstone-White et al. 2007). Distances traveled by pronghorn between winter and summer ranges can differ greatly among populations and between years. Pronghorn in this study traveled migratory distances comparable to those reported in South Dakota $(\bar{x}=23.1 \mathrm{~km}$; Jacques et al. 2009b), southern Idaho and Montana $(\bar{x}=44.5 \mathrm{~km}$; Hoskinson and Tester 1980), and southeastern Oregon (30-40 km; Dalton 2009). One individual during this study traveled $>160 \mathrm{~km}$, which is within the range of some of the longest seasonal migrations (116-258 km) reported for pronghorn (Wyoming; Sawyer et al. 2005, Berger and Cain 2014).

Female pronghorn generally demonstrate stronger fidelity to summer ranges and weaker fidelity to winter ranges (Deblinger and Alldredge 1984, Kolar et al. 2011, this study). Female pronghorn occupying sagebrush habitats of the northern Great Basin also exhibited a mixture of migration strategies. Not all pronghorn migrated similarly from the same winter ranges, or even with respect to their own previous migrations or travel routes. The individuals in this study that either did not migrate or only migrated a short distance the first year, but migrated long distances the following year support observations by White et al. (2007) and Jacques et al. (2009b) that migration in some pronghorn populations may be a conditional strategy. The proportion of pronghorn that migrated in this study ranged from $65 \%$ in $2011 / 2012$ to $100 \%$ in $2012 / 2013$ during harsher winter conditions; although the majority also made exploratory movements during fall 2011. Pronghorn may avoid adverse conditions by differing their migration strategy across years (e.g., Bruns 1977, Hoskinson and Tester 1980, Barrett 1984, Kolar et al. 2011). The proportion of migratory individuals within a population can vary greatly among regions, ranging from 8\%-19\% (Jacques et al. $2009 \mathrm{~b})$ to $70 \%-81 \%$ of individuals migrating annually (White et al. 2007). Such partial migration strategies are associated with costs to the individual weighed against increased access to higher-quality resources, and have been documented in several ungulate species including pronghorn, elk, and mule deer (Odocoileus hemionus) (Bergerud et al. 1990, Nicholson et al. 1997, White et al. 2007).

Across their range, pronghorn appear to respond to several key landscape features including physiography, vegetation, and movement barriers when selecting seasonal home ranges and migratory routes. Pronghorn 
home-range sizes are also highly variable. Previous estimates for adult pronghorn have ranged from 11.9 to $779.8 \mathrm{~km}^{2}$ (Wright and deVos 1986, Clemente et al. 1995, O’Gara and Yoakum 2004). Such variable home-range sizes are likely related to differences in habitat quality, population and group sizes, land-use practices, and seasonal requirements (Kitchen and O'Gara 1982). In general, pronghorn seasonally tend to use higher elevations during summer months, and then descended to lower elevations during the winter (Hoskinson and Tester 1980, Sawyer et al. 2005, White et al. 2007, this study). Pronghorn may make such seasonal elevational shifts to avoid deep snow due to difficulties encountered in both foraging and traveling. In the Great Basin, prolonged snow accumulation over $25-30 \mathrm{~cm}$ has been suggested to be detrimental to pronghorn when associated with low quantity and/or low quality of forage and barriers to movement (Sundstrom 1969, Riddle and Oakley 1973, Bruns 1977, Kindschy et al. 1982). When snow is present, pronghorn seek areas that have blown free or areas with low snow cover through which forage is accessible (Bruns 1977). Pronghorn have also been observed to make long-distance movements after a heavy snowfall in search of better forage accessibility (e.g., Guenzel et al. 1982, Sawyer and Lindzey 2000).

Typically, outside of elevational-related migration, pronghorn generally move north in the spring and south in the fall to warmer winter ranges (Sawyer et al. 2005, Sheldon and Lindzey 2006, Kolar et al. 2011). In contrast, pronghorn in the northern Great Basin demonstrated wide variation in directional movements between seasonal ranges and between years. Overall, marked pronghorn did follow a north-south gradient within the study area. However the directionality was not consistent (i.e., some individuals moved south in the fall and north in the spring, others moved south in the spring and north in the fall, and yet others explored in both directions during the fall migration period). As such, there was high overlap of common areas utilized by individual pronghorn across seasons and time periods, which additionally highlights these as important use areas. Individuals using routes during the fall migration period frequently, and sometimes repeatedly, bypassed each other while traveling in different directions, both through movement areas and through summer and winter ranges. Indeed, the majority of individual pronghorn made exploratory movements during the fall 2011 migration period, likely in response to an earlier onset of snow accumulation. Other studies have also identified individuals with extended migration periods (e.g., Sheldon and Lindzey 2006), presumably during which those pronghorn were making similar exploratory movements. In contrast, in 2012/2013, the onset of snow was later, but snow accumulated more quickly. Subsequently, only 2 individuals made long-distance exploratory movements during the fall 2012 migration period before settling on their respective winter ranges. Kolar et al. (2011) hypothesized that milder winters (i.e., warmer temperatures with less snow cover) would result in decreased migration distances. This hypothesis is supported by findings in this study where during 2012/2013, fall migration distances were longer with fewer exploratory movements compared to distances observed during 2011/2012 in more mild winter conditions. Winter ranges were also larger, lower in elevation, and shifted in location during 2012/2013, again corresponding to winter conditions that were on average colder with deeper snow.

Migratory ungulates are declining worldwide, and a broader conservation effort that includes recognizing migration routes as critical habitat is needed (Berger 2004, Bolger et al. 2008, Sawyer et al. 2009, Berger et al. 2014). The cumulative effects of climate change, habitat fragmentation, encroachment of invasive species, woodland expansion, increasing fire frequency and severity, and competition for water and forage resources with livestock and free-roaming horses are all challenging and ongoing conservation issues in the northern Great Basin (Miller et al. 2011, Manier et al. 2013). As such, successful longterm conservation of migratory pronghorn populations, both in this region and across their distribution, should include managing for not only the range of important seasonal use areas, but also maintaining connectivity along routes. Connectivity within this population is high and presently there appear to be no substantial barriers to pronghorn movement in this portion of the northern Great Basin. However, gathering the necessary background information is the first crucial step for 
long-term conservation (Berger and Cain 2014), particularly for a species that demonstrates such variability across its range. By identifying the distribution and timing of pronghorn use across the larger landscape, land managers now have a baseline through which a prioritization process can be developed to identify those areas and routes of highest conservation value (Sawyer et al. 2009, Copeland et al. 2014). And although overlap with large, protected lands (e.g., national wildlife refuges) was high in this instance, it is clear that these areas are not large enough to encompass the entirety of this migratory species' needs. Future obstacles to migration could potentially extirpate routes and contribute to a loss of connectivity (Copeland et al. 2014, Seidler et al. 2014). Partnerships across land management agencies and other stakeholders in applying this knowledge to ongoing landscape-level conservation planning will be necessary to mitigate any future cumulative changes that have the potential to impact important pronghorn habitat or alter connectivity.

\section{ACKNOWLEDGMENTS}

This work was funded by the U.S. Fish and Wildlife Service and conducted under permits \#S34640 (Nevada) and \#138-11 (Oregon). M. Cox, C. Foster, C. Hampson, and P. Wolff provided input and review of capture protocols. Leading Edge Aviation (Lewiston, ID) provided helicopter capture services. J. Romero and J. Greenhalgh provided aerial telemetry and monitoring (Owyhee Air Research, Inc., Nampa, ID). I thank S. Kovach for invaluable guidance with ArcGIS, GME, and Python and $\mathrm{R}$ programming. J. Kasbohm, D. Miller, P. Steblein, and $\mathrm{R}$. West were instrumental in ongoing project support. P. Emerson (JL Aviation, Boring, OR), B. Day, A. Collins, C. Foster, F. Healy, J. Kasbohm, K. López, and S. Ludwig assisted with collar retrievals. Comments from A. Collins, J. Kasbohm, S. Kovach, and S. Ludwig improved early drafts of the manuscript. I appreciate the critical insights of the editors and anonymous reviewers. The findings and conclusions in this article are those of the author and do not necessarily represent the views of the U.S. Fish and Wildlife Service. Any use of trade, product, or firm names is for descriptive purposes only and does not imply endorsement by the U.S. Government.

\section{Literature Cited}

Avital, E., AND E. JablonKa. 2000. Animal traditions: behavioral inheritance in evolution. Cambridge University Press, Cambridge, United Kingdom.

Barnowe-Meyer, K.K., P.J. White, L.P. Waits, and J.A. BYERS. 2013. Social and genetic structure associated with migration in pronghorn. Biological Conservation 168:108-115.

Barrett, M.W. 1984. Movements, habitat use, and predation on pronghorn (Antilocapra americana) fawns in Alberta. Journal of Wildlife Management 48:542-550.

Beckmann, J.P., K. Murray, R.G. Seidler, and J. Berger. 2012. Human-mediated shifts in animal habitat use: sequential changes in pronghorn use of a natural gas field in Greater Yellowstone. Biological Conservation 147:222-233.

Berger, J. 2004. The last mile: how to sustain long-distance migration in mammals. Conservation Biology 18: $320-331$.

Berger, J., AND S.L. Cain. 2014. Moving beyond science to protect a mammalian migration corridor. Conservation Biology 28:1142-1150.

Berger, J., S.L. Cain, and K. Murray Berger. 2006. Connecting the dots: an invariant migration corridor links the Holocene to the present. Biology Letters 2:528-531.

Berger, J.S., S.L. Cain, E. Cheng, P. Dratch, K. Ellison, J. Francis, H.C. Frost, S. Gende, C. Groves, W.A. KaRESh, ET AL. 2014. Optimism and challenge for science-based conservation of migratory species in and out of U.S. national parks. Conservation Biology 28:4-12.

Bergerud, A.T., R. Ferguson, and H.E. Butler. 1990. Spring migration and dispersion of woodland caribou at calving. Animal Behavior 39:360-368.

Boccadori, S.J., AND R.A. GarrotT. 2002. Effects of winter range on a pronghorn population in Yellowstone National Park. Proceedings of the Biennial Pronghorn Antelope Workshop 20:114.

Boccadori, S.J., P.J. White, R.A. GarrotT, J.J. Borkowski, AND T.L. DAVIS. 2008. Yellowstone pronghorn alter resource selection after sagebrush decline. Journal of Mammalogy 89:1031-1040.

Bolger, D.T., W.D. Newmark, T.A. Morrison, and D.F. DOAK. 2008. The need for integrative approaches to understand and conserve migratory ungulates. Ecology Letters 11:63-77.

BRuns, E.H. 1977. Winter behavior of pronghorns in relation to habitat. Journal of Wildlife Management 41:560-571.

Chambers, J.C., D.A. Pyke, J.D. Maestas, M. Pellant, C.S. Boyd, S.B. Campbell, S. Espinosa, D.W. Havlina, K.E. Mayer, and A. Wuenschel. 2014. Using resistance and resilience concepts to reduce impacts of invasive annual grasses and altered fire regimes on the sagebrush ecosystem and Greater Sage-Grouse: a strategic multi-scale approach. General Technical Report RMRS-GTR-326, Rocky Mountain Research Station, USDA Forest Service, Fort Collins, CO.

Clemente, F.R., R. Valdez, J.L. Holechek, P.J. Zwank, and M. Cardenas. 1995. Pronghorn home range relative to permanent water in southern New Mexico. Southwestern Naturalist 40:38-41.

Collins, G.H. 2014a. Results of the July 2014 aerial big game survey on Hart Mountain National Antelope 
Refuge. Unpublished report, U.S. Fish and Wildlife Service, Lakeview, OR.

Collins, G.H. 2014b. Results of the July 2014 aerial big game survey on Sheldon National Wildlife Refuge. Unpublished report, U.S. Fish and Wildlife Service, Lakeview, OR.

Copeland, H.E., H. Sawyer, K.L. Monteith, D.E. NaUgle, A. Pocewicz, N. Graf, and M.J. Kauffman. 2014. Conserving migratory mule deer through the umbrella of sage-grouse. Ecosphere 5:1-16.

DALTON, K.A. 2009. Pronghorn: migration triggers and resource selection in southeastern Oregon. Master's thesis, Washington State University, Pullman, WA.

Davies, K.W., C.S. Boyd, J.L. BECK, J.D. Bates, T.J. SvejCaR, AND M.A. GregG. 2011. Saving the sagebrush sea: an ecosystem conservation plan for big sagebrush plant communities. Biological Conservation 144: 2573-2584.

Deblinger, R.D., And A.W. Alldredge. 1984. Migratory patterns of pronghorn in the Red Desert, Wyoming. Proceedings of the Biennial Pronghorn Antelope Workshop 11:90-91.

Di Orio, A.P., R. Callas, and R.J. Schaefer. 2003. Performance of two GPS telemetry collars under different habitat conditions. Wildlife Society Bulletin 31: 372-379.

Dow, S.A., AND P.L. WRIGHT. 1962. Changes in mandibular dentition associated with age in pronghorn antelope. Journal of Wildlife Management 26:1-18.

Foster, C.L. 1988. Migration of Fort Rock and Duncan Reservoir pronghorn, Oregon. Proceedings of the Biennial Pronghorn Antelope Workshop 13:72-82.

Gates, C.C., P. Jones, M. Suitor, A. Jakes, M.S. Boyce, K. KUNKEL, AND K. Wilson. 2012. The influence of land use and fences on habitat effectiveness, movements, and distribution of pronghorn in the grasslands of North America. Pages 277-294 in M.J. Somers and M.W. Hayward, editors, Fencing for conservation: restriction of evolutionary potential or a riposte to threatening processes? Spring Science + Business Media, LLC. dx.doi.org/10.1007/ 978-1-4614-0902-1_15

Guenzel, R.J., L.L. IrWin, and T.J. Ryder. 1982. A comparison of pronghorn movements and distributions during a normal and mild winter in the Red Rim area, Wyoming. Proceedings of the Tenth Biennial Pronghorn Antelope Workshop 10:156-173.

Gustafson, E.J., AND R.H. GARDNER. 1996. The effect of landscape heterogeneity on the probability of patch colonization. Ecology 77:94-107.

Hebblewhite, M., and D.T. Haydon. 2010. Distinguishing technology from biology: a critical review of the use of GPS telemetry data in ecology. Philosophical Transactions of the Royal Society 365:2303-2312.

Horne, J.S., E.O. Garton, S.M. Krone, and J.S. Lewis. 2007. Analyzing animal movements using Brownian bridges. Ecology 88:2354-2363.

Hoskinson, R.L., and J.R. Tester. 1980. Migration behavior of pronghorn in southeastern Idaho. Journal of Wildlife Management 44:132-144.

JACQUES, C.N. 2006. Evaluation of aerial transect surveys, survival, and movements of pronghorns in western South Dakota. Doctoral dissertation, South Dakota University, Brookings, SD.

Jacques, C.N., J.A. Jenks, C.S. Deperno, J.D. Sievers, T.W. Grovenburg, T.J. Brinkman, C.C. Swanson, AND B.A. Stillings. 2009a. Evaluating ungulate mortality associated with helicopter net-gun captures in the northern Great Plains. Journal of Wildlife Management 73:1282-1291.

Jacques, C.N., J.A. Jenks, and R.W. Klaver. 2009b. Seasonal movements and home-range use by female pronghorns in sagebrush-steppe communities of western South Dakota. Journal of Mammalogy 90: 433-441.

Kindschy, R.R., C. Sundstrom, and J.D. Yoakum. 1982. Wildlife habitats in managed rangelands-the Great Basin of southeastern Oregon: pronghorns. General Technical Report GTR PNW-145, Pacific Northwest Forest and Range Experiment Station.

Kitchen, D.W., and B.W. O'Gara. 1982. Pronghorn, Antilocapra americana. Pages 960-972 in J.A. Chapman and G.A. Feldhammer, editors, Wild mammals of North America: biology, management, and economics. Johns Hopkins University Press, Baltimore, MD.

Knick, S.T., D.S. Dobkin, J.T. RotTenberry, M.A. Schroeder, W.M. Vander HaEgen, and C.V. RiPER. 2003. Teetering on the edge or too late? Conservation and research issues for avifauna of sagebrush habitats. Condor 105:611-634.

Kolar, J.L., J.J. Millspaugh, and B.A. Stillings. 2011. Migration patterns of pronghorn in southwestern North Dakota. Journal of Wildlife Management 75: 198-203.

Manier, D.J., D.J.A. Wood, Z.H. Bowen, R.M. Donovan, M.J. Holloran, L.M. Juliusson, K.S. Mayne, S.J. Oyler-McCance, F.R. Quamen, D.J. Saher, Et al. 2013. Summary of science, activities, programs, and policies that influence the range wide conservation of Greater Sage-Grouse (Centrocercus urophasianus). U.S. Geological Survey Open-File Report 2013-1098.

Miller, R.F., S.T. Knick, D.A. Pyke, C.W. Meinke, S.E. Hauser, J.J. Wisdom, AND A.L. Hild. 2011. Characteristics of sagebrush habitats and limitations to long-term conservation. Pages 145-185 in S.T. Knick and J.W. Connelly, editors, Greater Sage-Grouseecology and conservation of a landscape species and its habitats. Studies in Avian Biology 38, University of California Press, Berkeley, CA.

Natural Resources Conservation Service. 2014. SNOTEL data: Disaster Peak, Sheldon, Summit Lake, Silves, Strawberry. [Accessed 24 February 2014]. http://www.wcc.nrcs.usda.gov/snow/

Nicholson, M.C., R.T. Bowyer, AND J.G. KiE. 1997. Habitat selection and survival of mule deer: tradeoffs associated with migration. Journal of Mammalogy 38:541-545.

Nielson, R.M., H. Sawyer, and T.L. McDonald. 2013. Package 'BBMM'. Version 3.0. [Accessed 7 October 2014]. http://cran.fhcrc.org/

Noss, R.F., E.T. LaRoe III, AND J.M. SCOTT. 1995. Endangered ecosystems of the United States: a preliminary assessment of loss and degradation. National Biological Service Biological Report 28. Washington, DC

O'Gara, B.W., AND J.D. Yoakum. 2004. Pronghorn ecology and management. Wildlife Management Institute, Washington, DC.

PIPER, W.H. 2011. Making habitat selection more "familiar": a review. Behavioral Ecology and Sociobiology 65: 1329-1351.

R Development Core Team. 2013. R: a language and environment for statistical computing. Version 3.0.1. $\mathrm{R}$ Foundation for Statistical Computing. Vienna, Austria. 
Riddle, P., AND C. OAKLey. 1973. The impact of a severe winter and fences on antelope mortality in southcentral Wyoming. Proceedings of the Western Association of State Fish and Game Commissioners 53:174-188.

Saher, D.J., And F.K.A. Schmiegelow. 2005. Movement pathways and habitat selection by woodland caribou during spring migration. Rangifer 16:143-154.

Sawyer, H., M.J. Kauffman, R.M. Nielson, and J.S. HoRne. 2009. Identifying and prioritizing ungulate migration routes for landscape-level conservation. Ecological Applications 19:2016-2025.

SAWYER, H., AND F. LinDZEY. 2000. Jackson Hole pronghorn study. Report. Wyoming Cooperative and Wildlife Research Unit, University of Wyoming, Laramie, WY.

Sawyer, H., F. Lindzey, and D. MCWhirTer. 2005. Mule deer and pronghorn migration in western Wyoming. Wildlife Society Bulletin 33:1266-1273.

Schroeder, M.A., C.L. Aldrige, A.D. Apa, J.R. Bohne, C.E. Braun, S.D. Bunnell, J.W. Connelly, P.A. Diebert, S.C. Gardner, M.A. Hilliard, et al. 2004. Distribution of sage-grouse in North America. Condor 106:363-376.

Seidler, R.G., R.A. Long, J. Berger, S. Bergen, and J.P. BECKMANN. 2014. Identifying impediments to longdistance mammal migrations. Conservation Biology 29:99-109.

Sheldon, D., AND F. LindZey. 2006. Movement and distribution patterns of pronghorn in relation to roads and fences in southwestern Wyoming. Report. Wyoming Cooperative and Wildlife Research Unit, University of Wyoming, Laramie, WY.

SundSTROM, C. 1969. Some factors influencing pronghorn antelope distribution in the Red Desert of Wyoming. Proceedings of the Western Association of State Fish and Game Commissioners 49:255-264.

Trainer, C.E., M.J. Willis, G.P. Keister Jr., and D.P. SheEhy. 1983. Fawn mortality and habitat use among pronghorn during spring and summer in southeastern Oregon, 1981-1982. Wildlife Research Report 12, Oregon Department of Fish and Wildlife, Portland, OR.

White, P.J., T.L. Davis, K.K. Barnowe-Meyer, R.L. Crabtree, and R.A. Garrott. 2007. Partial migration and philopatry of Yellowstone pronghorn. Biological Conservation 135:502-510.

Wisdom, M.J., M.M. RoWLAND, AND L.H. SuRING, EDITORS. 2005. Habitat threats in the sagebrush ecosystem: methods of regional assessment and applications in the Great Basin. Alliance Communication Group, Lawrence, KS.

Wright, R.L., AND J.C. DEVos JR. 1986. Final report on Sonoran pronghorn status in Arizona. Arizona Department of Game and Fish, Phoenix, AZ.

Received 22 April 2015 Accepted 30 September 2015 